medRxiv preprint doi: https://doi.org/10.1101/2021.06.08.21258480; this version posted June 10, 2021. The copyright holder for this preprint (which was not certified by peer review) is the author/funder, who has granted medRxiv a license to display the preprint in perpetuity. It is made available under a CC-BY-NC-ND 4.0 International license.

COVID-19 in pregnancy

\title{
SARS-CoV-2 infection in pregnancy in Denmark - characteristics and outcomes after confirmed infection in pregnancy: a nationwide, prospective, population-based cohort study
}

Anna JM Aabakke, MD, $\mathrm{PhD}^{1,2}$, Lone Krebs, MD, DMSc ${ }^{2,3}$, Tanja G Petersen, MScPH, $\mathrm{PhD}^{4}$, Frank S Kjeldsen, $\mathrm{MScPH}^{4}$, Giulia Corn ${ }^{5}$, Karen Wøjdemann, MD, $\mathrm{PhD}^{6}$, Mette H Ibsen, $\mathrm{MD}^{7}$, Fjola Jonsdottir, $\mathrm{MD}^{8}$, Elisabeth Rønneberg, $\mathrm{MD}^{8}$, Charlotte S Andersen ${ }^{9}$, Iben Sundtoft, $\mathrm{MD}, \mathrm{PhD}^{9}$, Tine Clausen, $\mathrm{MD}$, $\mathrm{PhD}^{2,10}$, Julie Milbak ${ }^{10}$, Lars Burmester, $\mathrm{MD}^{11}$, Birgitte Lindved, $\mathrm{MD}^{12}$, Annette Thorsen-Meyer, $\mathrm{MD}^{3}$, Mohammed R Khalil, MD, $\mathrm{PhD}^{13}$, Birgitte Henriksen ${ }^{13}$, Lisbeth Jønsson, $\mathrm{MD}^{14}$, Lise LT Andersen, $\mathrm{MD}^{15}$, Kamilla K Karlsen, MD, $\mathrm{PhD}^{15}$, Monica L Pedersen ${ }^{16}$, Åse Klemmensen, MD, $\mathrm{PhD}^{17}$, Marianne Vestgaard, $\mathrm{MD}, \mathrm{PhD}^{17}$, Dorthe Thisted, $\mathrm{MD}^{18}$, Manrinder K Tatla, $\mathrm{MD}^{18}$, Line S Andersen, $\mathrm{MD}^{19}$, Anne-Line Brülle ${ }^{20}$, Arense Gulbech, MD ${ }^{20}$, Charlotte B Andersson, MD ${ }^{21,22}$, Richard Farlie, MD, MHM ${ }^{23}$, Lea Hansen ${ }^{24}$, Lone Hvidman, MD, $\mathrm{PHD}^{24}$, Anne N Sørensen, MD, PhD ${ }^{25}$, Sidsel L Rathcke, $\mathrm{MD}^{25}$, Katrine H Rubin, PhD, $\mathrm{MHS}^{4,26}$, Lone K Petersen, MD, DMSc ${ }^{15,26}$, Jan S Jørgensen, MD, PhD ${ }^{15,26}$, Lonny Stokholm, MScPH ${ }^{4,26}$, Mette Bliddal, $\mathrm{PhD}^{4,26}$

1. Department of Obstetrics and Gynecology, Copenhagen University Hospital - Holbæk, Holbæk, Denmark

2. Department of Clinical Medicine, University of Copenhagen, Copenhagen, Denmark

3. Department of Obstetrics and Gynecology, Copenhagen University Hospital - Amager and Hvidovre, Hvidovre, Denmark

4. OPEN - Open Patient data Explorative Network, Odense University Hospital, Odense, Denmark

5. Department of Epidemiology Research and Division of Infectious Diseases Preparedness, Statens Serum Institut, Copenhagen, Denmark

6. Department of Obstetrics and Gynecology, Copenhagen University Hospital - Bornholm, Rønne, Denmark

7. Department Obstetrics and Gynecology, Hospital of South West Jutland, Esbjerg, Denmark

8. Department of Obstetrics and Gynecology, Copenhagen University Hospital - Herlev and Gentofte,

Herlev, Denmark

9. Department Obstetrics and Gynecology, Regional Hospital West Jutland, Herning, Denmark

10. Department of Obstetrics and Gynecology, Copenhagen University Hospital - North Zealand, Hillerød,

Denmark

11. Department of Obstetrics and Gynecology, The North Denmark Regional Hospital Hjørring, Hjørring,

Denmark

12. Department of Obstetrics and Gynecology, Horsens Regional Hospital, Horsens, Denmark

13. Department Obstetrics and Gynecology, University Hospital of Southern Denmark - Kolding, Kolding,

Denmark

14. Department Obstetrics and Gynecology, Nykøbing F. Hospital, Nykøbing F, Denmark

15. Department of Obstetrics and Gynecology, Odense University Hospital, Odense, Denmark

16. Department of Obstetrics and Gynecology, Randers Regional Hospital, Randers, Denmark

17. Department of Obstetrics and Gynecology, Copenhagen University Hospital - Rigshospitalet,

Copenhagen, Denmark

18. Department of Obstetrics and Gynecology, Zealand University Hospital, Roskilde, Denmark

19. Department of Obstetrics and Gynecology, Copenhagen University Hospital - Slagelse, Slagelse,

Denmark

20. Department of Obstetrics and Gynecology, Hospital of South Jutland, Aabenraa, Denmark

21. Department of Obstetrics and Gynecology, The North Denmark Regional Hospital Thisted, Thisted,

Denmark

22. Danish Center for Clinical Health Services Research (DACS), Aalborg, Denmark.

23. Department of Obstetrics and Gynecology, Viborg Regional Hospital, Viborg, Denmark

24. Department of Obstetrics and Gynecology, Aarhus University Hospital, Aarhus, Denmark

25. Department of Obstetrics and Gynecology, Aalborg University Hospital, Aalborg, Denmark

26. Department of Clinical Research, University of Southern Denmark, Odense, Denmark 
medRxiv preprint doi: https://doi.org/10.1101/2021.06.08.21258480; this version posted June 10, 2021. The copyright holder for this preprint (which was not certified by peer review) is the author/funder, who has granted medRxiv a license to display the preprint in perpetuity. It is made available under a CC-BY-NC-ND 4.0 International license .

COVID-19 in pregnancy

\section{Abstract}

\section{Introduction}

Assessing the risk factors for and consequences of infection with SARS-CoV-2 during pregnancy is essential to guide clinical guidelines and care. Previous studies on the influence of SARS-CoV-2 infection in pregnancy have been among hospitalised patients, which may have exaggerated risk estimates of severe outcomes because all cases of SARS-CoV-2 infection in the pregnant population were not included. The objectives of this study were to identify risk factors for and outcomes after SARS-CoV-2 infection in pregnancy independent of severity of infection in a universally tested population, and to identify risk factors for and outcomes after severe infection requiring hospital admission.

\section{Material and Methods}

This was a prospective population-based cohort study in Denmark using data from the Danish National Patient Register and Danish Microbiology Database and prospectively registered data from medical records. We included all pregnancies between March 1 and October 31, 2020 and compared women with a positive SARS-CoV-2 test during pregnancy to non-infected pregnant women. Cases of SARS-CoV-2 infection in pregnancy were both identified prospectively and through register linkage to secure that all cases were identified and that cases were pregnant during infection. Main outcome measures were pregnancy, delivery, maternal, and neonatal outcomes. Severe infection was defined as hospital admission due to COVID-19.

\section{Results}

Among 82682 pregnancies, 418 women had SARS-CoV-2 infection during pregnancy, corresponding to an incidence of 5.1 per 1000 pregnancies, 23 (5.5\%) of which required hospital admission due to COVID-19. Risk factors for infection were asthma (OR 2.19 [1.41-3.41]) and being foreign born (OR 2.12 [1.70-2.64]). Risk factors for hospital admission due to COVID-19 included obesity (OR 2.74 [1.00-7.51]), smoking (OR 4.69 [1.58-13.90]), infection after gestational age (GA) 22 weeks (GA 22-27 weeks: OR 3.77 [1.16-12.29]; GA 28-36 weeks: OR 4.76 [1.60-14.12]) and having asthma (OR 4.53 [1.39-14.79]). We found no difference in any obstetric or neonatal outcomes. 
medRxiv preprint doi: https://doi.org/10.1101/2021.06.08.21258480; this version posted June 10, 2021 . The copyright holder for this preprint (which was not certified by peer review) is the author/funder, who has granted medRxiv a license to display the preprint in perpetuity. It is made available under a CC-BY-NC-ND 4.0 International license.

COVID-19 in pregnancy

\section{Conclusions}

Only 1 in 20 women with SARS-CoV-2 infection during pregnancy require admission to hospital due to COVID-19. And severe outcomes of SARS-CoV-2 infection in pregnancy are rare.

\section{Keywords}

Severe acute respiratory syndrome coronavirus 2; COVID-19; Obstetric delivery; Pregnancy complications; Pregnancy outcome; Cohort studies; Prospective studies.

\section{Abbreviations}

BMI: Body mass index

CI: Confidence interval

COVID-19: Coronavirus disease

DCOD: the Danish COVID-19 in pregnancy database

DNPR: The Danish National Patient Register

EDD: Estimated date of delivery

GA: Gestational age in completed weeks

HR: Hazard ratio

ICU: Intensive care unit

IQR: Interquartile range

LMP: Date of the first day of the last menstrual period

MiBa: Danish Microbiology Database

NICU: Neonatal intensive care unit

OR: Crude odds ratio

PCR: Polymerase chain reaction

SARS-CoV-2: Severe acute respiratory syndrome coronavirus 2

W: Weeks

\section{Key Message}

Population based cohort study about SARS-CoV-2 infection during pregnancy. Asthma and foreign ethnicity were identified as risk factors for infection while obstetric outcomes did not change. Obesity, smoking, infection after GA 22, and asthma increased the risk of hospital admission. 
medRxiv preprint doi: https://doi.org/10.1101/2021.06.08.21258480; this version posted June 10, 2021. The copyright holder for this preprint (which was not certified by peer review) is the author/funder, who has granted medRxiv a license to display the preprint in perpetuity. It is made available under a CC-BY-NC-ND 4.0 International license .

COVID-19 in pregnancy

\section{Main body of Text}

\section{Introduction}

The World Health Organisation declared a global pandemic of coronavirus disease (COVID-19) in March 2020. ${ }^{1}$ COVID-19 is caused by infection with severe acute respiratory syndrome coronavirus 2 (SARS-CoV-2).

Assessing the risk factors for and consequences of infection with SARS-CoV-2 during pregnancy is essential to guide clinical guidelines and care.

Evidence indicates that pregnant women are not at increased risk of infection with SARS-CoV-2 compared to non-pregnant women..$^{2-4}$ Risk factors associated with infection include obesity, age, ethnicity, and pre-existing morbidities, and SARS-CoV-2 infection in pregnancy has been associated with an increased risk of admission to an intensive care unit (ICU), preterm delivery, and admission of the neonate to a neonatal intensive care unit (NICU). ${ }^{5-9}$

Most previous population-based studies on SARS-CoV-2 infection in pregnancy have been among hospitalised patients, which may have exaggerated risk estimates of severe outcomes because all cases of SARS-CoV-2 infection in the pregnant population were not included. ${ }^{6,10}$ Only one study from the Netherlands included all cases independent of severity. ${ }^{7}$ However, in that study cases were identified prospectively in obstetric clinics, with the risk of selection bias. Additionally, the outcomes are in most studies compared to outcomes of historic cohorts of non-infected women, with the risk that the consequences of the pandemic will be attributed solely to SARS-CoV-2.6,7,11 Lastly, testing strategies influence the estimated prevalence of SARS-CoV-2 infection, and potentially also the estimated severity of outcomes in that also the mild and asymptomatic cases detected. $^{5}$

The testing strategy in Denmark rapidly evolved during the pandemic from testing the most ill in March 2020 to testing cases with mild symptoms from April and testing close contacts from May. Universal testing of all pregnant women admitted to hospital including those for delivery was implemented nationwide in early May 2020.

The objectives of this study were to identify risk factors for SARS-CoV-2 infection in pregnancy in a universally tested population and risk factors for severe infection requiring hospital admission, and to investigate the consequences of infection and severe infection on pregnancy, delivery, and neonatal outcomes when comparing to all non-infected pregnancies during the same time period. 
medRxiv preprint doi: https://doi.org/10.1101/2021.06.08.21258480; this version posted June 10, 2021. The copyright holder for this preprint (which was not certified by peer review) is the author/funder, who has granted medRxiv a license to display the preprint in perpetuity. It is made available under a CC-BY-NC-ND 4.0 International license .

COVID-19 in pregnancy

\section{Material and methods}

This was a nationwide prospective population-based study investigating the association between SARS-CoV-2 infection in pregnancy and clinical characteristics and maternal, delivery, and neonatal outcomes. The study used prospectively registered data from medical records registered in the Danish COVID-19 in pregnancy database (DCOD) and register data obtained from the following national registers: the Danish National Patient Register (DNPR), ${ }^{12}$ Danish Microbiology Database (MiBa), ${ }^{13}$ and the Civil Registration System. ${ }^{14}$

The overall study population was identified in DNPR and comprised all women registered with a pregnancy or birth-related ICD10 diagnosis or procedure between March 1 and October 31, 2020 as specified in Table S1. SARS-CoV-2-positive cases within the study population were identified by linkage to MiBa. In Denmark, all positive polymerase chain reaction (PCR) tests are registered in $\mathrm{MiBa}$, while antigen and antibody tests were not during the study period. Pregnant women identified in the registers were followed up until December 11, 2020.

In the DCOD, women with a positive SARS-CoV-2 test during pregnancy between March 1 and October 31, 2020 were registered prospectively. Eligible SARS-CoV-2 tests included PCR tests (of pharyngeal swab or tracheal secretion), antigen tests (of nasal swab), or detection of antibodies (in a blood test) combined with a history of COVID-19 symptoms during pregnancy. All obstetric units in Denmark participated, and clinicians from each unit reported cases based on data in the medical records. DCOD was based in EasyTrial (easytrial.net, Denmark). Cases were validated every second month by register linkage, with data obtained from the DNPR, Danish National Service Register, and $\mathrm{MiBa}$. The validation dataset included only personal identification number, date of positive SARS-CoV-2 PCR test, date of hospital contact, and name of the hospital. Non-reported cases identified by validation who were pregnant at the time of a positive SARS-CoV-2 PCR test were entered into the DCOD retrospectively. Women included in the DCOD were followed up until data extraction on February 8, 2021.

The register data on the overall study population were pseudoanonymised, making it impossible to validate the SARS-CoV-2-positive cases from the registers against the DCOD cases on an individual level. We therefore present data for SARS-CoV-2-positive women from the DCOD alongside cases identified in the registers to illustrate degree of comparability. SARS-CoV-2 cases in the DCOD and those registered in the national registries were each compared to the non-infected population. The validity of maternal and neonatal characteristics, surgical procedures, and main 
medRxiv preprint doi: https://doi.org/10.1101/2021.06.08.21258480; this version posted June 10, 2021. The copyright holder for this preprint (which was not certified by peer review) is the author/funder, who has granted medRxiv a license to display the preprint in perpetuity. It is made available under a CC-BY-NC-ND 4.0 International license .

COVID-19 in pregnancy

diagnoses in the Danish registers is considered high, ${ }^{15}$ and we therefore evaluated that a comparison between the DCOD data and the registry data was relevant.

The estimated date of delivery (EDD) was registered in the DCOD and based on the first trimester ultrasound examination offered to all pregnant women between gestational age (GA) 11 and 14 completed weeks (w). In case of first trimester abortion, the EDD was calculated based on the GA at abortion. In the DCOD, date of the first day of the last menstrual period (LMP) was defined as EDD minus 280 days. In the register data, the LMP was calculated based on the registered GA at delivery or abortion. If still pregnant, we calculated the LMP based on GA at ultrasound examination, and if missing, the recommended GA for the registered ultrasound examinations. For abortions with a missing registration of GA, GA was imputed based on the mean GA within the categories miscarriage or induced abortion.

Characteristics included maternal age at LMP, body mass index (BMI) based on pre-pregnancy weight as registered at first contact in pregnancy, smoking defined as any smoking during pregnancy, parity, multiple pregnancy, pre-eclampsia, gestational diabetes, and diabetes. The register dataset also included pre-existing asthma, and hypertension diagnosed within 5 years of LMP. Table S2 presents the codes used to identify characteristics and outcomes in DNPR. The DCOD also included information on migrant status defined as not born in Denmark, employment status including ongoing education, asthma defined as asthma requiring steroid inhalation, preexisting medical problems and previous pregnancy-related complications as specified in Table S3.

Maternal outcomes included admission to an ICU, pneumonia (in the DCOD defined as confirmed by radiological examination), thromboembolic events, maternal mortality (death during pregnancy or within 7 days postpartum) and pregnancy outcomes including delivery, termination of pregnancy before GA 23 w, or miscarriage before GA 22 w.

Delivery outcomes comprised mode of delivery, induction of labour, and preterm birth before GA $37 \mathrm{w}$.

Neonatal outcomes included admission to a NICU directly from the delivery or maternity ward, stillbirth from GA $22 \mathrm{w}$, Apgar score at 5 minutes, umbilical artery $\mathrm{pH}$, and neonatal death (within 28 days postpartum).

Data on migrant status and infant admission to a NICU were not available in our register data. These variables registered in the DCOD were therefore compared to historical data comprising 
medRxiv preprint doi: https://doi.org/10.1101/2021.06.08.21258480; this version posted June 10, 2021. The copyright holder for this preprint (which was not certified by peer review) is the author/funder, who has granted medRxiv a license to display the preprint in perpetuity. It is made available under a CC-BY-NC-ND 4.0 International license.

COVID-19 in pregnancy

migrant status of all women with a liveborn child in 2019 in Denmark as reported by Statistics Denmark $^{16}$ and admissions to a NICU of all live born children in Denmark in 2019 as reported by the Danish Quality Database for new-borns. ${ }^{17}$

In the DCOD, admission to hospital with a concurrent SARS-CoV-2 infection was defined as admission and discharge on two different dates and a positive SARS-CoV-2 test within 14 days before or during admission. Severe infection was defined as admission to hospital due to COVID19 symptoms.

\section{Statistical Analyses}

Categorical variables are presented as count with percentage, and continuous variables as median with interquartile range (IQR). For DCOD data numbers $<3$ and for register data numbers $<5$ are not reported to avoid identification according to the respective ethical approvals. The categorical DCOD data were analysed by calculating the odds ratio and with chi $^{2}$ test when compared to the non-infected population, and with logistic regression when compared to severe versus non-severe DCOD cases including multivariate analyses adjusting for age, BMI, parity, and smoking.

Continuous DCOD variables were analysed using the Wilcoxon signed rank test. We did a subanalysis of the DCOD cases testing for the influence of gestational age at time of SARS-CoV-2 infection on key outcomes comprising cesarean delivery, induction of labour, preterm birth, and NICU admission. In the analysis of register data, categorical outcomes were assessed with univariate and multiple logistic regression and continuous variables with linear regression. The multivariate analyses adjusted for a) maternal age and LMP to adjust for time of inclusion in the study, and b) predefined risk factors including maternal age, LMP, parity, BMI, and smoking. In the linear regression model, we included log-transformed outcome variables, applying bootstrapping to account for non-normal distribution of residuals. For the outcomes miscarriage, termination of pregnancy, and preterm delivery, a Cox regression analysis was performed, including SARS-CoV-2 as time-dependent exposure, to account for duration of exposure to SARS-CoV-2 during follow-up. For the first three outcomes, women were included in the survival-analysis according to the time of first registered hospital contact, and for preterm delivery, women were included at GA 100 days and registered as SARS-CoV-2 exposed at the date of positive test. Missing data were excluded from all analyses. A $P$-value $\leq 0.05$ was considered statistically significant. Data were analysed using Stata/MP16 (64-bit) and IBM SPSS statistics 27 (SPSS Inc). 
medRxiv preprint doi: https://doi.org/10.1101/2021.06.08.21258480; this version posted June 10, 2021. The copyright holder for this preprint (which was not certified by peer review) is the author/funder, who has granted medRxiv a license to display the preprint in perpetuity. It is made available under a CC-BY-NC-ND 4.0 International license .

COVID-19 in pregnancy

\section{Ethical Approval}

The study was approved by the Danish Patient Safety Authority on the April 24, 2020 (reg. no. 311521-252), the regional Data Protection Agency in Region Zealand on the March 23, 2020 (reg. no. REG-022-2020), and the regional Data Protection Agency in Region of Southern Denmark on April 15, 2020 (reg. no. 20/17416). The study is reported according to STROBE guidelines. ${ }^{18}$

\section{Results}

Among 82682 pregnancies in Denmark between March 1 and October 31, 2020, 420 women had a SARS-CoV-2 positive PCR-test, and 418 SARS-CoV-2 cases were confirmed as being during pregnancy through validation against medical records. Figure 1A illustrates the flow through the register-based part of the study, and Figure 1B the flow through the DCOD study.

The overall incidence of SARS-COV-2 infection during validated pregnancy in the inclusion period was 5.1 (95\% confidence interval (CI) 4.7-5.5) per 1000 pregnancies, with the monthly incidence ranging from 0.2 per 1000 pregnancies in July to 3.8 in October (Figure S1). Of the SARS-CoV-2 cases in pregnancy, 23 (5.5\%) were admitted to hospital because of severe COVID-19 symptoms.

Basic characteristics of women and their pregnancies according to SARS-CoV-2 status and severity of infection are presented in Table 1 and Table S4. Pregnant women infected with SARS-CoV-2 more frequently had pre-existing asthma (crude odds ratio (OR) 2.19, 95\% CI 1.41-3.41) and were foreign born (OR 2.12, 95\% CI 1.70-2.64) compared to the non-infected. There were no differences in the rates of pre-eclampsia or gestational diabetes. Women who required admission to hospital had a significantly higher BMI $(P=0.018)$, were more likely to smoke in pregnancy $(\mathrm{OR} 4.69,95 \%$ CI 1.58-13.90), and have pre-existing asthma (OR 4.53, 95\% CI 1.39-14.79). Compared to women becoming infected before, women becoming infected after GA $22 \mathrm{w}$ had a higher risk of COVID19-related hospital admission (GA 22-27 w: OR 3.77, 95\% CI 1.16-12.29; GA 28-36 w: OR 4.76, 95\% CI 1.60-14.12).

The outcomes of the SARS-CoV-2 infected women compared to all non-infected pregnancies are presented in Table 2. The rate of pneumonia among SARS-CoV-2 infected pregnant women was $1.5 \%(n=6)$, corresponding to a significantly higher risk compared to non-infected pregnancies (OR 15.97, 95\% CI 6.92-36.86). The rate of thromboembolic events and admission to an ICU was low, and we had no cases of maternal death during the study period. The rate of early pregnancy loss did not vary between the groups after adjusting for exposure time. However, the risk of 
medRxiv preprint doi: https://doi.org/10.1101/2021.06.08.21258480; this version posted June 10, 2021. The copyright holder for this preprint (which was not certified by peer review) is the author/funder, who has granted medRxiv a license to display the preprint in perpetuity. It is made available under a CC-BY-NC-ND 4.0 International license .

COVID-19 in pregnancy

termination of pregnancy was increased after adjustment (Hazard Ratio (HR) 2.39, 95\% CI 1.294.45) among the SARS-CoV-2 infected women. The median time between SARS-CoV-2 infection and delivery was 88 days (interquartile range 35-138). We found no difference between the groups regarding any of the delivery or infant outcomes. Adjustment did not change the results. We had no neonatal deaths among the children of SARS-CoV-2 infected women.

We found no difference in outcomes between women with severe COVID-19 infection requiring hospital admission compared to less severe SARS-CoV-2 cases in either the crude or adjusted analyses (Table 3).

There was no difference in risk of cesarean delivery, induction of labour, preterm birth, or NICU admission in relation to GA at infection among the SARS-CoV-2 infected women (data not shown).

\section{Discussion}

In this prospective population-based cohort study, we found 418 validated cases of SARS-CoV-2 among pregnant women, corresponding to an incidence of 5.1 per 1000 pregnancies. Only 23 women (5.5\%) required hospital admission due to the COVID-19 infection. Risk factors for infection were asthma and being foreign born, while obesity, smoking in pregnancy, infection after GA $22 \mathrm{w}$, and having asthma increased the risk of hospital admission due to COVID-19. We found an increased risk of late termination of pregnancy, but no difference in any delivery or neonatal outcomes among infected women. Severity of infection did not affect outcomes.

Minority ethnicity has been identified as a risk factor for SARS-CoV-2 infection in both pregnant and non-pregnant women. ${ }^{5-8,11}$ The increased risk level found in this study is similar to that reported in a large systematic review. ${ }^{5}$ The aetiology of the ethnic disparity is not clear, but it is probably multifaceted and related to cultural and socioeconomic factors rather than to SARS-CoV-2.

The identified risk factors for severe infection comprising asthma, increasing maternal weight, and GA at the time of infection are similar to risk factors identified in previous studies. ${ }^{5,6}$ Smoking in pregnancy has not been described previously, but seems a plausible risk factor due to its effect on lung tissue. Previous population-based studies have primarily included women admitted to hospital, ${ }^{6,10,11}$ and our results in the more severe cases (Table 3 ) are therefore comparable to the results of these studies.

Women with SARS-CoV-2 infection had, expectedly, a much higher risk of pneumonia, but otherwise we found no increased risk for adverse maternal or neonatal outcomes in infected 
medRxiv preprint doi: https://doi.org/10.1101/2021.06.08.21258480; this version posted June 10, 2021. The copyright holder for this preprint (which was not certified by peer review) is the author/funder, who has granted medRxiv a license to display the preprint in perpetuity. It is made available under a CC-BY-NC-ND 4.0 International license .

COVID-19 in pregnancy

compared to non-infected pregnant women. Previous studies have found increased risks of admission to an ICU, induction of labour, preterm delivery, and admission to a NICU, ${ }^{5-9,19,20}$ which we could not confirm. The lack of association in our study might be related to the fact that we included all cases of SARS-CoV-2 infection in pregnancy independent of severity. The previously shown associations between SARS-CoV-2 and severe outcomes might be related to severity of disease. Albeit, we found no difference in outcomes among cases requiring hospital admission due to COVID-19 compared to less severe cases. Nevertheless, in a Nordic collaborative study, women with severe COVID-19 were at increased risk of induction of labour, cesarean delivery, and preterm delivery. ${ }^{21}$

We found few cases of early pregnancy complications among the SARS-CoV-2 infected women. However, after adjustment for exposure time, the risk of termination of pregnancy was higher among the SARS-CoV-2 infected women. In Denmark, all women admitted to hospital are tested for SARS-CoV-2, and we assume that the increased rate of terminations is partly related to more frequent testing and consequently a higher detection rate of SARS-CoV-2 among women opting for provoked abortion rather than the SARS-CoV-2 diagnosis itself. However, an association cannot be ruled out and future studies are needed to explore whether there is a possible association between SARS-CoV-2 infection and terminations of pregnancy.

This study has several strengths. The major strength is the combination of register-based data considered complete ${ }^{12}$ and prospectively collected medical record data, allowing for validation, analysis of disease severity, and multivariate analyses. Furthermore, the comparison population comprised all pregnancies from the same inclusion period as the SARS-CoV-2 cases, thus adjusting for the possible consequences of community regulations during a pandemic. ${ }^{22}$ Additionally, we identified the vast majority of SARS-CoV-2 cases in pregnancy because testing was widespread in Denmark during the inclusion period, and the DCOD data were validated against registry data.

The study also has limitations. First, the register dataset was pseudoanonymised, making individuallevel linkage to DCOD impossible. Additionally, data on SARS-CoV-2 cases in the DCOD were based on medical records and data in the national registers were based on mandatory nationally registered data, and these data might not be directly comparable. Nevertheless, the number of SARS-CoV-19 cases was similar in the two cohorts, and data did not differ significantly between the cohorts, indicating agreement between cases and data sources. Some descriptive variables including BMI and smoking status are not reported in the registers before delivery and are not 
medRxiv preprint doi: https://doi.org/10.1101/2021.06.08.21258480; this version posted June 10, 2021 . The copyright holder for this preprint (which was not certified by peer review) is the author/funder, who has granted medRxiv a license to display the preprint in perpetuity. It is made available under a CC-BY-NC-ND 4.0 International license.

COVID-19 in pregnancy

reported for early pregnancy losses. The DCOD thus provided complete data, and made national surveillance of the infection possible to support national guidelines until register data were available. ${ }^{23-25}$ Secondly, the lack of association in some outcomes for severe cases might be due to low numbers. Thirdly, universal testing of pregnant women was not implemented in Denmark before May 2020, and we might therefore have missed SARS-CoV-2-positive cases early in the inclusion period. Furthermore, MiBa only included information on PCR tests, thus missing pregnant women diagnosed through antigen or antibody tests, which were possibly milder cases. Inclusion of these plausibly positive but non-identified cases in the comparison population of pregnancies might have affected our estimates.

\section{Conclusion}

In this prospective population-based cohort study with universal SARS-CoV-2 testing, we found no difference in outcomes related to delivery or the neonate among infected women compared to noninfected, nor did severity of infection affect the results. The results indicate that the outcomes of SARS-CoV-2 infection in pregnancy might not be as severe as proposed by previous studies in which more severe cases were included. Testing strategy and how cases are included naturally influence the results and should be considered.

We found that the incidence of termination of pregnancy among SARS-CoV-2 infected women was increased compared to that in non-infected pregnant women, which might be related to universal screening of women admitted to hospital. Further studies are needed to explore a possible relation between late termination of pregnancy and SARS-CoV-2 infection. 
medRxiv preprint doi: https://doi.org/10.1101/2021.06.08.21258480; this version posted June 10, 2021. The copyright holder for this preprint (which was not certified by peer review) is the author/funder, who has granted medRxiv a license to display the preprint in perpetuity. It is made available under a CC-BY-NC-ND 4.0 International license .

COVID-19 in pregnancy

\section{Acknowledgement}

The authors would like to thank EasyTrial, who provided their clinical trial management software, used for data management in the DCOD study, free of charge for this study as the company offered free access to the software to COVID-19 research projects.

The authors also wish to thank Professor Marian Knight, DPhil, National Perinatal Epidemiology Unit, Nuffield Department of Population Health, University of Oxford, UK, for her initiation of the International Network of Obstetric Survey Systems study, in which the DCOD participates, and her contribution to the international case report form, on which the DCOD is based.

\section{Conflicts of Interests}

All authors declare no conflict of interest

\section{Funding Information}

This study was supported by grants from the Danish Ministry of Higher Education and Science (Reg. no. 0237-00007B), The Region of Southern Denmark and Region Zealand's shared fund for joint health research projects (Reg. no. A767) and The Nordic Federation of Societies of Obstetrics and Gynecology (NFOG).

The funding sources had no influence on the study design, data collection and analysis, interpretation of data, preparation of the manuscript, or decision to submit the paper.

\section{Author Contributions}

AA, LK, MB, LS, KHR, JJ, LP conceived the registry study, and AA and LK conceived the DCOD study. AA, LK, MB designed and planned the combined study. AA, MB, TP, FP acquired and analysed the data for the cohort study. KW, MI, FJ, ER, CA, IS, TC, JM, LB, BL, AT, MK, BH, LJ, SS, LS, KK, MP, ÅK, MV, DT, MT, LA, AB, AG, CBA, RF, LH, LHv, AS, SR, AA, and LK acquired and managed the DCOD dataset and AA analysed the DCOD data. AA wrote the first draft of the manuscript, MB, LK, TP, LS, KHR and JJ revised the manuscript critically, and all authors approved the final version of the manuscript. All authors accept responsibility for the paper. 
medRxiv preprint doi: https://doi.org/10.1101/2021.06.08.21258480; this version posted June 10, 2021. The copyright holder for this preprint (which was not certified by peer review) is the author/funder, who has granted medRxiv a license to display the preprint in perpetuity. It is made available under a CC-BY-NC-ND 4.0 International license .

COVID-19 in pregnancy

\section{References}

1. World Health Organization. Rolling updates on coronavirus disease (COVID-19). Available online at: https://www.who.int/emergencies/diseases/novel-coronavirus-2019/events-as-they-happen. (Accessed August 13, 2020).

2. Docherty AB, Harrison EM, Green CA, et al. Features of 20133 UK patients in hospital with covid-19 using the ISARIC WHO Clinical Characterisation Protocol: prospective observational cohort study. BMJ. Published online May 22, 2020:m1985. doi:10.1136/bmj.m1985

3. Smith V, Seo D, Warty R, et al. Maternal and neonatal outcomes associated with COVID-19 infection: A systematic review. Ryckman KK, ed. PLOS ONE. 2020;15(6):e0234187.

4. Prabhu M, Cagino K, Matthews KC, et al. Pregnancy and postpartum outcomes in a universally tested population for SARS-CoV-2 in New York City: a prospective cohort study. BJOG Int J Obstet Gynaecol. Published online July 7, 2020. doi:10.1111/1471-0528.16403

5. Allotey J, Stallings E, Bonet M, et al. Clinical manifestations, risk factors, and maternal and perinatal outcomes of coronavirus disease 2019 in pregnancy: living systematic review and meta-analysis. $B M J$. Published online September 1, 2020:m3320. doi:10.1136/bmj.m3320

6. Vousden N, Bunch K, Morris E, et al. The incidence, characteristics and outcomes of pregnant women hospitalized with symptomatic and asymptomatic SARS-CoV-2 infection in the UK from March to September 2020: a national cohort study using the UK Obstetric Surveillance System (UKOSS). medRxiv. Published online January 5, 2021:2021.01.04.21249195. doi:10.1101/2021.01.04.21249195

7. Overtoom EM, Rosman, Ageeth N, Swart, Joost J, et al. SARS-CoV-2 infection in pregnancy during the first wave of COVID-19 in teh Netherlands: a prospective nationwide population-based cohort study. Authorea. Published online October 9, 2020. doi:10.22541/au.160224307.78021677/v1

8. Jering KS, Claggett BL, Cunningham JW, et al. Clinical Characteristics and Outcomes of Hospitalized Women Giving Birth With and Without COVID-19. JAMA Intern Med. Published online January 15, 2021. doi:10.1001/jamainternmed.2020.9241

9. Zambrano LD, Ellington S, Strid P, et al. Update: Characteristics of Symptomatic Women of Reproductive Age with Laboratory-Confirmed SARS-CoV-2 Infection by Pregnancy Status - United States, January 22-October 3, 2020. MMWR Morb Mortal Wkly Rep. 2020;69(44):1641-1647.

10. Maraschini A, Corsi E, Salvatore MA, Donati S, ItOSS COVID-19 Working Group. Coronavirus and birth in Italy: results of a national population-based cohort study. Ann Ist Super Sanita. 2020;56(3):378-389.

11. Knight M, Bunch K, Vousden N, et al. Characteristics and outcomes of pregnant women admitted to hospital with confirmed SARS-CoV-2 infection in UK: national population based cohort study. BMJ. 2020;369:m2107.

12. Schmidt M, Schmidt SAJ, Sandegaard JL, Ehrenstein V, Pedersen L, Sørensen HT. The Danish National Patient Registry: a review of content, data quality, and research potential. Clin Epidemiol. 2015;7:449-490.

13. Voldstedlund M, Haarh M, Mølbak K, MiBa Board of Representatives. The Danish Microbiology Database (MiBa) 2010 to 2013. Euro Surveill Bull Eur Sur Mal Transm Eur Commun Dis Bull. $2014 ; 19(1)$. 
medRxiv preprint doi: https://doi.org/10.1101/2021.06.08.21258480; this version posted June 10, 2021. The copyright holder for this preprint (which was not certified by peer review) is the author/funder, who has granted medRxiv a license to display the preprint in perpetuity. It is made available under a CC-BY-NC-ND 4.0 International license.

COVID-19 in pregnancy

14. Pedersen CB, Gøtzsche H, Møller JO, Mortensen PB. The Danish Civil Registration System. A cohort of eight million persons. Dan Med Bull. 2006;53(4):441-449.

15. Bliddal M, Broe A, Pottegård A, Olsen J, Langhoff-Roos J. The Danish Medical Birth Register. Eur J Epidemiol. 2018;33(1):27-36.

16. Statistics Denmark. Available online at: https://statistikbanken.dk/FODIE (Accessed February 4, 2021).

17. Dansk Kvalitetsdatabse for Nyfødte (DKN). Datakvalitetsrapport 2019. Available online at: https://www.sundhed.dk/content/cms/73/102373_dkn_datakvalitetsrapport2019_offentliggoerelse_04022021.pdf (Accessed February 19, 2021).

18. Vandenbroucke JP, von EE, Altman DG, et al. Strengthening the Reporting of Observational Studies in Epidemiology (STROBE): explanation and elaboration. Epidemiology. 2007;18:805-835.

19. Woodworth KR, Olsen EO, Neelam V, et al. Birth and Infant Outcomes Following LaboratoryConfirmed SARS-CoV-2 Infection in Pregnancy - SET-NET, 16 Jurisdictions, March 29-October 14, 2020. MMWR Morb Mortal Wkly Rep. 2020;69(44):1635-1640.

20. Villar J, Ariff S, Gunier RB, et al. Maternal and Neonatal Morbidity and Mortality Among Pregnant Women With and Without COVID-19 Infection: The INTERCOVID Multinational Cohort Study. JAMA Pediatr. Published online April 22, 2021. doi:10.1001/jamapediatrics.2021.1050

21. Engjom H, Aabakke AJ, Klungsøyr K, et al. COVID-19 in pregnancy - characteristics and outcomes of pregnant women admitted to hospital because of SARS-CoV-2 infection in the Nordic countries. Acta Obstet Gynecol Scand. doi:https://doi.org/10.1111/aogs.14160

22. Chmielewska B, Barratt I, Townsend R, et al. Effects of the COVID-19 pandemic on maternal and perinatal outcomes: a systematic review and meta-analysis. Lancet Glob Health. Published online March 31, 2021. doi:10.1016/S2214-109X(21)00079-6

23. Aabakke AJM, Krebs L. COVID-19 i Graviditet, Rapport for Perioden 1. Marts - 30. August 2020. Available online at:

https://static1.squarespace.com/stahttps://static1.squarespace.com/static/5467abcce4b056d72594db79/t 15f7ef92c2c1737355da5b769/1602156846868/COVID-19+i+graviditet+-+Rapport+for+martsaugust+v1.1.pdftic/5467abcce4b056d72594db79/t/5ecfe76495025343e22ccb07/1590683493294/Bilag +F+-+COVID-19+i+graviditet+-+Rapport+for+marts-april+2020_final.pdf (Accessed November 27, 2020 .

24. Aabakke AJM, Krebs L. COVID-19 i Graviditet. Rapport for Perioden 1. Marts - 31. Oktober 2020. Available online at: https://static1.squarespace.com/static/5467abcce4b056d72594db79/t/6046795aaee5296b9de96066/161 5231323325/COVID-19+i+graviditet+-+Rapport+for+marts-oktober+v1.1.pdf (Accessed March 23, 2021).

25. Aabakke AJM, Krebs L. COVID-19 i Graviditet. Rapport for Perioden 1. Marts - 30. April 2020. Available online at:

https://static1.squarespace.com/static/5467abcce4b056d72594db79/t/5ecfe76495025343e22ccb07/1590 683493294/Bilag+F+-+COVID-19+i+graviditet+-+Rapport+for+marts-april+2020_final.pdf (Accessed March 23, 2021). 
medRxiv preprint doi: https://doi.org/10.1101/2021.06.08.21258480; this version posted June 10, 2021 . The copyright holder for this preprint (which was not certified by peer review) is the author/funder, who has granted medRxiv a license to display the preprint in perpetuity. It is made available under a CC-BY-NC-ND 4.0 International license.

COVID-19 in pregnancy

\section{Legends to figures and tables}

Figure 1. A) Flow through the register study; B) Flow through the Danish COVID-19 in pregnancy database (DCOD) study.

Table 1. Basic characteristics of SARS-CoV-2 infected women overall and according to severity of infection and all pregnant women in Denmark between March 1 and October 31, 2020.

Table 2. Outcomes for women with SARS-CoV-2 infection in pregnancy compared to all pregnancies in Denmark between March 1 and October 31, 2020.

Table 3. Outcomes for women with severe COVID-19 infection requiring admission to hospital compared to less severe SARS-CoV-2 cases in pregnancy in Denmark between March 1 and October 31, 2020 as registered in the Danish COVID-19 in pregnancy database (DCOD).

Table S1. Procedure and diagnostic codes used to identify the overall study population in the Danish National Patient Register (DNPR).

Table S2. Procedure and diagnostic codes used to identify basic characteristics and outcomes in the Danish National Patient Register (DNPR).

Table S3. Definition of pre-existing medical problems and previous pregnancy-related complications in DCOD.

Table S4: Additional basic characteristics of SARS-CoV-2 infected women overall and according to severity of infection and all pregnant women in Denmark between March 1 and October 31, 2020.

Figure S1: Absolute number of SARS-CoV-2 positive cases and overall incidence per 1000 pregnancies per month in Denmark between March 1 and October 31, 2020. 
A) Flow through the register study

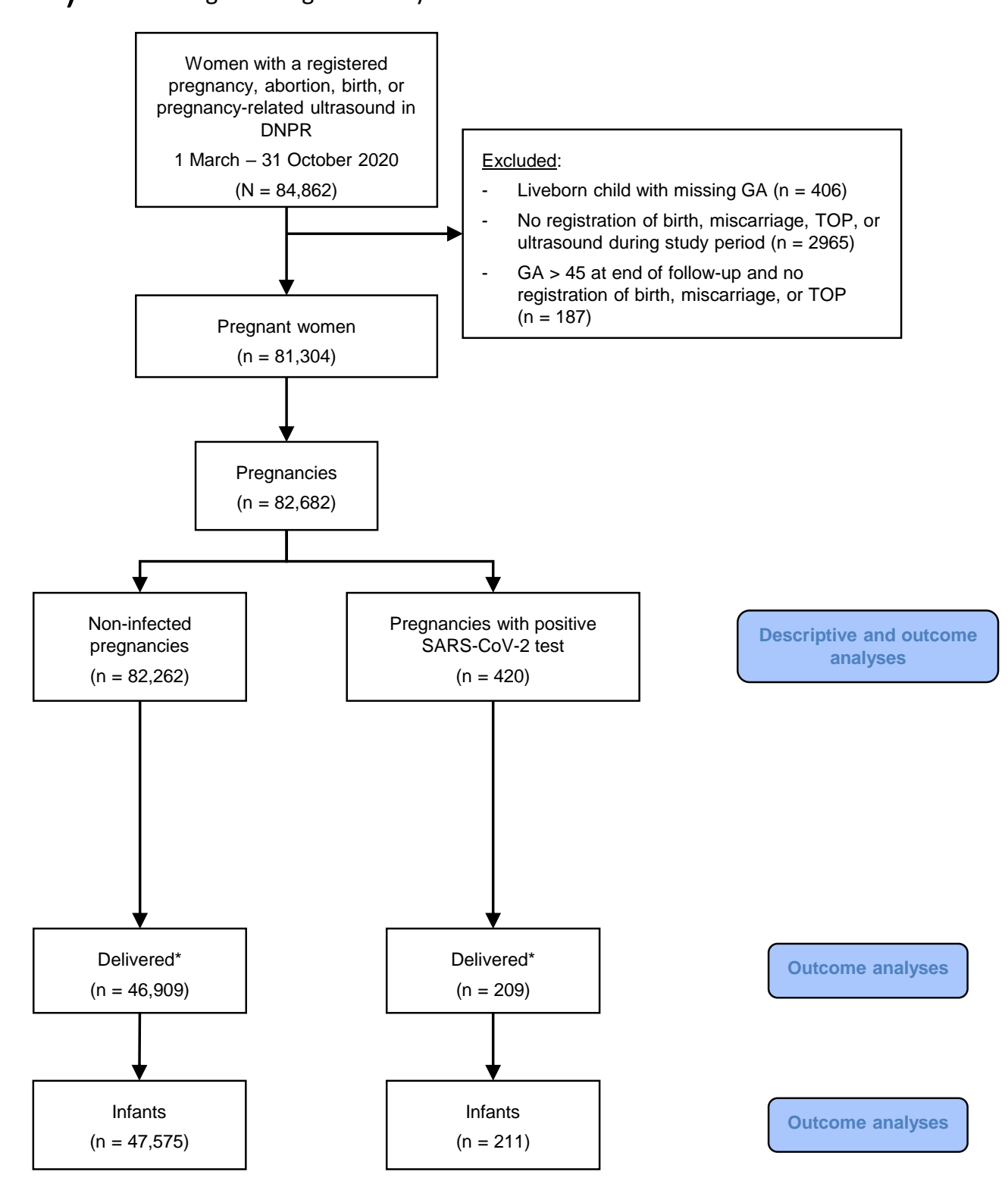

B) Flow through the Danish COVID-19 in pregnancy database (DCOD) study

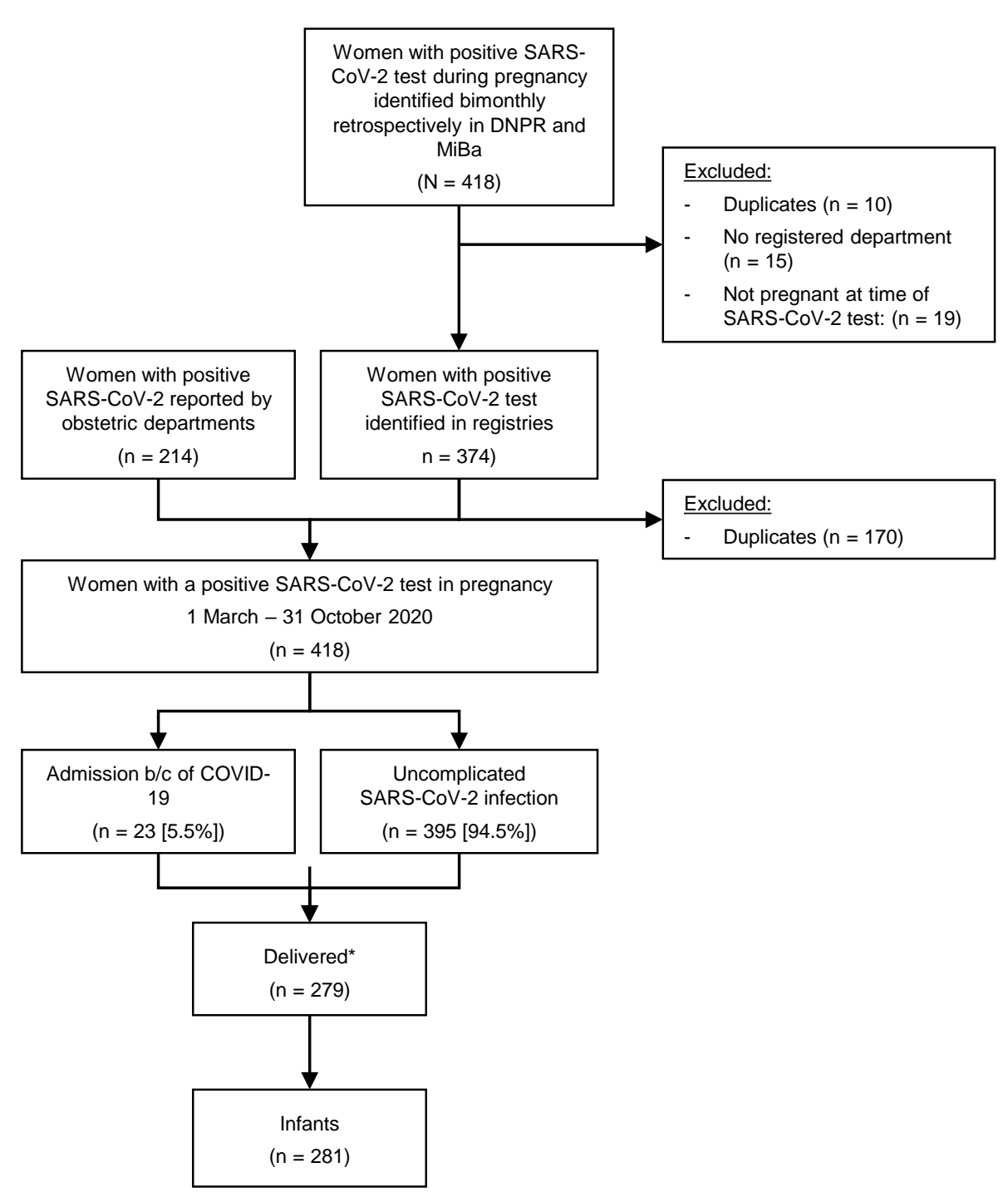


Table 1. Basic characteristics of SARS-CoV-2 infected women overall and according to severity of infection and all pregnant women in Denmark between March 1 and October 31, 2020.

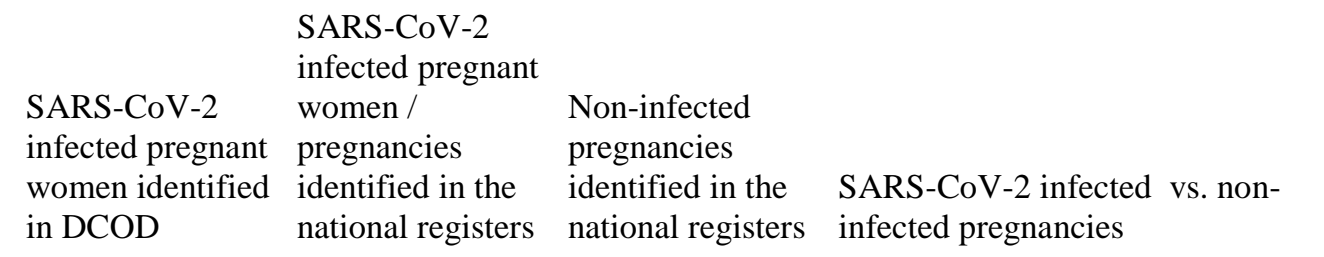

SARS-CoV-2 infected women identified in DCOD

Women requiring hospital admission due to COVID-19

symptoms vs.

Women requiring

admission to

hospital due to

DCOD SARS- Register SARS-

Women with

women with

uncomplicated uncomplicated

COVID-19 SARS-CoV-2 SARS-CoV-2

CoV-2 cases CoV-2 cases

symptoms

infection*

infection*

\begin{tabular}{|c|c|c|c|c|c|c|c|c|c|c|}
\hline & & $\mathrm{N}=418$ & $\mathrm{~N}=420$ & $\mathrm{~N}=82262$ & $\mathrm{OR}_{\mathrm{D}}(95 \% \mathrm{CI})$ & $\mathrm{OR}_{\mathrm{R}}(95 \% \mathrm{CI})$ & $\mathrm{N}=23$ & $\mathrm{~N}=395$ & $\mathrm{OR}_{\mathrm{DCOD}}(95 \% \mathrm{CI})$ & $P$ \\
\hline \multicolumn{11}{|l|}{$\begin{array}{l}\text { Basic } \\
\text { characteristics }\end{array}$} \\
\hline \multirow[t]{5}{*}{ Age } & $<25$ & $51(12.2)$ & 48 (11.4) & 10324 (12.6) & 1 (ref.) & 1 (ref.) & & & & \\
\hline & $25-34$ & $291(69.6)$ & $297(70.7)$ & $57372(69.7)$ & $1.02(0.75-1.41)$ & $1.11(0.82-1.51)$ & & & & \\
\hline & $\geq 35$ & $76(18.2)$ & 75 (17.9) & $14566(17.7)$ & $1.05(0.73-1.53)$ & $1.11(0.77-1.59)$ & & & & \\
\hline & $\geq 30$ & & & & & & $10(43.5)$ & $185(47.0)$ & $0.87(0.37-2.03)$ & \\
\hline & $\begin{array}{l}\text { median } \\
<25\end{array}$ & $29.6(27.0-33.4)$ & $29.0(27.0-33.0)$ & $30.0(27.0-33.0)$ & NA & $0.99(0.97-1.01)$ & $29.9(25.4-33.2)$ & $29.5(27.0-33.5)$ & & 0.750 \\
\hline \multirow[t]{7}{*}{ BMI } & $\begin{array}{l}\text { (normal) } \\
25-29.9\end{array}$ & $241(60.3)$ & $113(55.1)$ & $27083(58.5)$ & 1 (ref.) & 1 (ref.) & $10(43.5)$ & $232(61.4)$ & 1 (ref) & \\
\hline & (overweight) & $93(23.3)$ & $61(29.8)$ & 11904 (25.7) & $0.88(0.68-1.12)$ & $1.23(0.90-1.68)$ & $6(26.1)$ & $87(23.0)$ & $1.60(0.56-4.52)$ & \\
\hline & $\begin{array}{l}\geq 30 \text { (obese) } \\
30-34.9\end{array}$ & & & & & & 7 (30.4) & $59(15.6)$ & $2.74(1.00-7.51)$ & \\
\hline & (obese) & $44(11.0)$ & $23(11.2)$ & $4609(9.9)$ & $1.07(0.75-1.48)$ & $1.20(0.76-1.87)$ & $>4$ & $<40$ & & \\
\hline & $\geq 35$ (obese) & $22(5.5)$ & $8(3.9)$ & $2729(5.9)$ & $0.91(0.56-1.41)$ & $0.70(0.34-1.44)$ & $<3$ & $>19$ & & \\
\hline & missing & $18(4.3)$ & $215(51.2)$ & 35937 (43.7) & & & $0(0)$ & $18(4.6)$ & & \\
\hline & $\begin{array}{l}\text { median } \\
\text { Smoking in }\end{array}$ & $24.1(26.9-33.4)$ & $24.0(22.0-27.0)$ & $24.0(21.0-27.0)$ & NA & $1.01(0.99-1.04)$ & $25.6(23.7-31.2)$ & $24.0(21.6-27.6)$ & & 0.018 \\
\hline \multirow[t]{2}{*}{ Smoking } & pregnancy & $27(6.8)$ & $10(4.9)$ & 3598 (7.9) & $0.86(0.58-1.27)$ & $0.60(0.32-1.13)$ & $5(22.7)$ & $22(5.9)$ & $4.69(1.58-13.90)$ & \\
\hline & Unknown & $23(5.5)$ & $214(51.0)$ & $36478(44.3)$ & & & $1(4.3)$ & $22(5.6)$ & & \\
\hline \multirow[t]{2}{*}{ Pre-existing asthma } & & $21(5.2)$ & $23(5.5)$ & $1996(2.4)$ & $2.19(1.41-3.41)$ & $2.33(1.53-3.56)$ & $4(17.4)$ & $17(4.4)$ & $4.53(1.39-14.79)$ & \\
\hline & Unknown & $12(2.9)$ & & & & & $0(0)$ & $12(3.0)$ & & \\
\hline
\end{tabular}


$82(20.2) \quad$ NA NA

Unknown $12(2.9)$

Migrant

$119(32.2)$

NA

$49(11.7)$
8 (34.8)

$0(0)$

$10(47.6)$

$2(8.7)$
$74(19.3)$

$12(3.0)$

$109(31.3)$

47 (11.9)
$2.23(0.91-5.45)$

$1.99(0.82-4.83)$

\section{COVID-19}

\section{characteristics}

GA at infection§ (in completed weeks)

$\begin{array}{llll}<22 & 191(45.8) & 211(50.2) & \text { NR } \\ 22-27 & 76(18.2) & 77(18.3) & \text { NR } \\ 28-36 & 97(23.3) & 89(21.2) & \text { NR } \\ 37- & 53(12.7) & 43(10.2) & \text { NR } \\ \text { unknown } & 1(0.2) & & \\ & 22 w 6 d(15 w 0 d- & 21 w 0 d(14 w 0 d- & \\ \text { Median } & 30 w 4 d) & 29 w 0 d) & \text { NR }\end{array}$

\begin{tabular}{l} 
Pregnancy \\
characteristics \\
\hline Parity
\end{tabular}

$\begin{array}{lll}5(21.7) & 186(47.2) & 1 \text { (ref) } \\ 7(30.4) & 69(17.5) & \mathbf{3 . 7 7}(\mathbf{1 . 1 6}-\mathbf{1 2 . 2 9}) \\ 11(47.8) & 86(21.8) & \mathbf{4 . 7 6}(\mathbf{1 . 6 0}-\mathbf{1 4 . 1 2}) \\ 0(0.0) & 53(13.5) & \mathrm{NR} \\ & 1(0.3) & \\ \text { 26w4d (23w4d- } & & \\ 32 \mathrm{w} 0 \mathrm{~d}) & 22 w 1 d(14 \mathrm{w} 4 \mathrm{~d}-30 \mathrm{w} 0 \mathrm{~d})\end{array}$

(n)

\begin{tabular}{|c|c|c|c|c|c|c|c|c|c|}
\hline \multirow[t]{2}{*}{ Parity } & Multiparous & $230(56.7)$ & $218(53.7)$ & $39727(55.1)$ & $1.07(0.88-1.30)$ & $0.95(0.78-1.15)$ & $16(69.6)$ & $219(56.4)$ & $1.76(0.71-4.39)$ \\
\hline & Unknown & $12(2.9)$ & $14(3.3)$ & $10156(12.3)$ & & & $0(0)$ & $7(1.8)$ & \\
\hline Multiple pregnancy & & $<3$ & $<5$ & $1005(1.2)$ & NA & NA & $0(0)$ & $<3$ & \\
\hline & Unknown & $4(1.0)$ & & & & & $0(0)$ & $4(1.0)$ & \\
\hline $\begin{array}{l}\text { Pre- } \\
\text { eclampsia/Eclampsia }\end{array}$ & & $<3$ & $6(1.4)$ & $1642(2.0)$ & NA & $0.71(0.32-1.60)$ & NA & NA & \\
\hline GDM & & $19(4.5)$ & $22(5.2)$ & $3353(4.1)$ & $1.12(0.71-1.78)$ & $1.30(0.85-2.00)$ & $<3$ & $>16$ & NA \\
\hline $\begin{array}{l}\text { Thromboembolic } \\
\text { event }\end{array}$ & & $<3$ & $0(0.0)$ & $62(0.1)$ & NA & NR & $0(0)$ & $<3$ & NA \\
\hline
\end{tabular}

Data are presented as count (\%) or median (interquartile range)

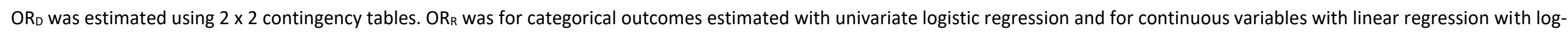
transformed dependant variable.

ORDCOD was estimated using logistic regression.

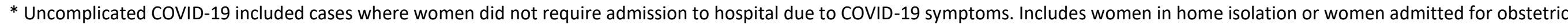
reason within 14 days of first positive COVID-19 test or symptoms.

† Pre-existing medical problems include endocrine, cardiac, renal, psychiatric, haematological, inflammatory and autoimmune disease, and cancer and HIV.

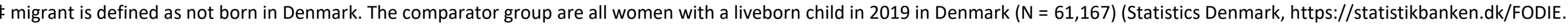
[accessed 4 Feb. 2021]).

$\S \mathrm{GA}$ at infection is defined as date of first positive test in case of a PCR test or date of symptoms in case of an antibody test. 
Table 2. Outcomes for women with SARS-CoV-2 infection in pregnancy compared to all pregnancies in Denmark between March 1 and October 31, 2020.

\begin{tabular}{|c|c|c|}
\hline & $\begin{array}{l}\text { SARS-CoV-2 } \\
\text { infected preonnant }\end{array}$ & \\
\hline $\begin{array}{l}\text { SARS-CoV-2 } \\
\text { infected pregnant } \\
\text { women identified } \\
\text { in DCOD }\end{array}$ & $\begin{array}{l}\text { women / } \\
\text { pregnancies } \\
\text { identified in the } \\
\text { national registers }\end{array}$ & $\begin{array}{l}\text { Non-infected } \\
\text { pregnancies } \\
\text { identified in the } \\
\text { national registers }\end{array}$ \\
\hline
\end{tabular}

SARS-CoV-2 infected vs. non-infected pregnancy* DCOD SARS-CoV-2

cases

Register SARS-CoV-2 cases

$\mathrm{OR}_{\mathrm{D}}(95 \% \mathrm{CI})$

$\mathrm{OR}_{\mathrm{R}}(95 \% \mathrm{CI}) \quad \mathrm{HR}_{\mathrm{a}}(95 \% \mathrm{CI})$

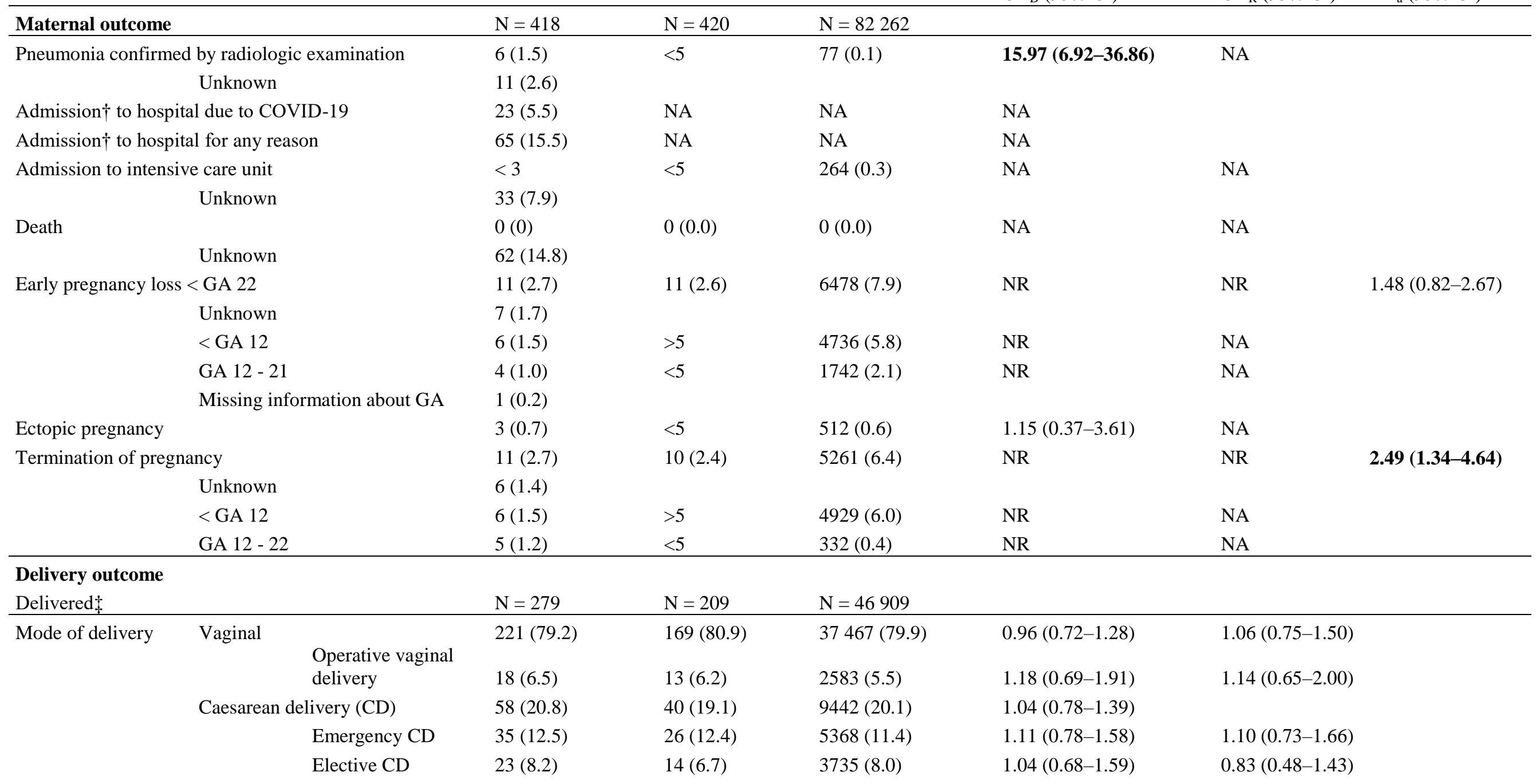


Preterm birth < GA

37

Median (IQR)

$13(4.7)$

40w0d (39w1d-

$12(5.7) \quad 2539(5.4)$

$0.85(0.49-1.49)$

$1.06(0.59-1.91) \quad 0.94(0.47-1.88)$

$41 \mathrm{w} 0 \mathrm{~d}$

40w6d)

$41 \mathrm{w} 0 \mathrm{~d})$

NA

$0.99(0.98-1.00)$

Interval between COVID-19 and delivery, days, median (IQR)

$88(35-138)$

$76(23-145)$ NR

\section{Infant outcome}

Number of infants

$\mathrm{N}>279$

$\mathrm{N}>209 \quad \mathrm{~N}=47575$

IUFD

Liveborn infants

$<3<5$

$134(0.3)$

$\mathrm{N}=279$

$\mathrm{N}=209$

$\mathrm{N}=4744$

NICU admission ${ }^{\S}$

28 (10.0)

COVID-19 infection in neonate

$$
\text { Unknown }
$$

$26(9.3)$

Congenital malformations

5 (1.8)

$1(0.4)$

$0(0)$

3 (1.1)

$<7$

$10(10.0-10.0)$

Median

Umbilical cord $\mathrm{pH}$

(arterial)

$$
\begin{aligned}
& <7.10 \\
& \text { Missing } \\
& \text { Median }
\end{aligned}
$$

$$
54 \text { (19.4) }
$$$$
7.24(7.18-7.27)
$$

$0(0.0)$

Neonatal death

5514 (9.3)

NA

NA

Data are presented as count (\%) or median (interquartile range)

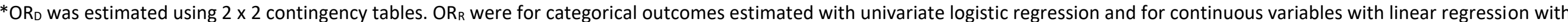
log-transformed dependant variable. HRa was estimated by a Cox regression adjusting for exposure time for relevant variables .

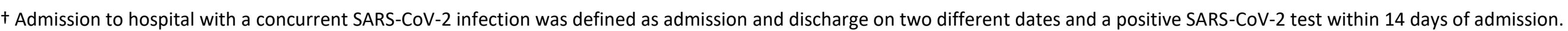

¥ The proportion of women, who had delivered at the time of analyses, varies due to different follow-up time in DCOD and the register data (please see methods section).

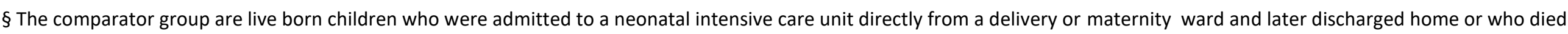

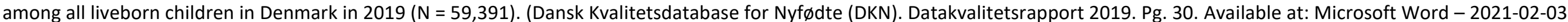
DKN_Datarapport_officiel (sundhed.dk) [Assessed 19 Feb 2021].

CD Caesarean delivery; DCOD Danish COVID-19 in pregnancy Database; GA Gestational age; IUFD Intrauterine fetal death; NICU Neonatal intensive care unit; NR Not relevant, ,

HRa: Adjusted for age and first day of the last menstrual period 
Table 3. Outcomes for women with severe COVID-19 infection requiring admission to hospital compared to less severe SARS-CoV-2 cases in pregnancy in Denmark between March 1 and October 31, 2020 as registered in the Danish COVID-19 in pregnancy database (DCOD).

SARS-CoV-2 infected women registered in DCOD

Women requiring

admission to hospital due Uncomplicated SARS-

to COVID-19 symptoms CoV-2 infection*

\begin{tabular}{|c|c|c|c|c|c|c|}
\hline & & $\mathrm{N}=23$ & $\mathrm{~N}=395$ & OR $(95 \% \mathrm{CI})$ & $P$ & $\mathrm{aOR}(95 \% \mathrm{CI})^{\dagger}$ \\
\hline Maternal outcome & & & & & & \\
\hline & & $\mathrm{N}=23$ & $\mathrm{~N}=395$ & & & \\
\hline Death & & $0(0)$ & $0(0)$ & NR & & \\
\hline & Missing information & $1(4.3)$ & $61(15.4)$ & & & \\
\hline EUG & & $0(0)$ & $3(0.8)$ & NR & & \\
\hline GA 23 & & $0(0)$ & $11(2.8)$ & NR & & \\
\hline & Unknown & $0(0)$ & $6(1.5)$ & & & \\
\hline Delivered & & $17(73.9)$ & $262(66.3)$ & $1.44(0.55-3.73)$ & & $1.74(0.62-4.93)$ \\
\hline Delivery outcome & & & & & & \\
\hline Delivered & & $\mathrm{N}=17$ & $\mathrm{~N}=262$ & & & \\
\hline Mode of delivery & & & & & & \\
\hline & Unassisted vaginal delivery & $11(64.7)$ & $192(73.3)$ & 1 (ref) & & 1 (ref) \\
\hline & Operative vaginal delivery & $0(0.0)$ & $18(6.9)$ & NR & & NR \\
\hline & Emergency CD & $3(17.6)$ & $32(12.2)$ & $1.64(0.43-619)$ & & $1.88(0.46-7.74)$ \\
\hline & Elective CD & $3(17.6)$ & $20(7.6)$ & $2.62(0.67-10.17)$ & & $3.81(0.85-17.09)$ \\
\hline Induction & & $7(41.2)$ & $65(24.8)$ & $2.12(0.78-5.80)$ & & $1.53(0.52-4.49)$ \\
\hline $\begin{array}{l}\text { Interval between COVID-19 } \\
\text { and delivery, days }\end{array}$ & & $62(42-103)$ & $91(35-138)$ & & 0.250 & \\
\hline Infant outcome & & & & & & \\
\hline Liveborn infants & & $\mathrm{N}=17$ & $\mathrm{~N}=262$ & & & \\
\hline GA at delivery & & $39 w 5 d(38 w 4 d-40 w 4 d)$ & 40w0d (39w1d-41w0d) & & 0.161 & \\
\hline Preterm birth < GA 37 & & $<3$ & $>10$ & NA & & \\
\hline NICU admission & & $4(23.5)$ & $24(9.2)$ & $3.05(0.92-10.10)$ & & $3.37(0.95-11.97)$ \\
\hline Gender & Boy & $8(47.1)$ & $121(46.2)$ & $1.04(0.39-2.77)$ & & $1.12(0.40-3.15)$ \\
\hline Weight at delivery, grams & & $3460(3109-3810)$ & $3475(3198-3859)$ & & 0.733 & \\
\hline APGAR 5 minutes & $<7$ & $0(0)$ & $0(0)$ & NR & & \\
\hline & Unknown & $0(0.0)$ & $3(1.1)$ & & & \\
\hline
\end{tabular}




\begin{tabular}{|c|c|c|c|c|c|}
\hline \multirow{3}{*}{ Umbilical cord pH (arterial) } & Median & $10(10-10)$ & $10(10-10)$ & & 0.170 \\
\hline & $<7.10$ & $0(0.0)$ & $8(3.7)$ & NR & \\
\hline & Unknown & $6(35.3)$ & $48(18.3)$ & & \\
\hline & Median & $7.23(7.17-1.28)$ & $7.24(7.18-7.27)$ & & 0.823 \\
\hline \multirow[t]{2}{*}{ Congenital malformations } & & $0(0.0)$ & $5(1.9)$ & NR & \\
\hline & Unknown & $0(0.0)$ & $1(0.4)$ & & \\
\hline Neonatal death & & $0(0.0)$ & $0(0.0)$ & NR & \\
\hline
\end{tabular}

Data are presented as count (\%) or median (interquartile range)

OR was estimated using logistic regression.

* Uncomplicated COVID-19 included cases where women did not require admission to hospital due to COVID-19 symptoms. Includes women in home isolation or women admitted for obstetric reason within 14 days of first positive COVID-19 test or symptoms.

†Adjusted for age, BMI, parity (nulli- or multiparity), and smoking

CD Caesarean delivery; DCOD Danish COvid-19 in pregnancy database; GA Gestational age; IUFD Intrauterine fetal death; NA not available; NICU Neonatal intensive care unit; NR not relevant 